\title{
LYMPHOCYTE-TRANSFORMING ACTIVITY OF STREPTO- COCCI BELONGING TO VARIOUS LANCEFIELD GROUPS
}

\author{
A. G. TAYLOR \\ Pathology Department, Institute of Orthopaedics \\ (University of London), Stanmore, Middlesex
}

THE lymphocyte-transforming activity of preparations of streptolysin S was first reported by Hirschhorn et al. (1964), and it has since been demonstrated that the mitogen is not the haemolysin itself (Plate and Amos, 1969; Taranta, Cuppari and Quagliata, 1969; Taylor, 1969). The production of the mitogen by streptococci does not depend on the presence of RNA used to induce formation of streptolysin S (Plate and Amos), but detailed studies of the conditions of culture under which the active material is formed have not been published. There is no information on the release of mitogen by streptococci other than the group-A strains (no. C203S and its non-haemolytic mutant no. C203U) used by Bernheimer (1949) in his original studies on streptolysin S.

Current interest in the mitogen is not only with respect to its action on lymphocytes in vitro but also to its possible effect on the immune response in streptococcal infections (Taranta et al.). In this study, 27 strains of group-A streptococci and 39 strains of other Lancefield groups have been examined for mitogenic activity.

\section{MATERIALS AND METHODS}

Streptococci. Strain no. C203S was originally obtained from Professor A. W. Bernheimer. All other strains were provided as freeze-dried cultures by Dr W. R. Maxted of the Streptococcus Reference Laboratory, Colindale, London; these were reconstituted with ToddHewitt broth, incubated at $37^{\circ} \mathrm{C}$ overnight, and tested for purity by culture on blood agar.

Culture of streptococci. Todd-Hewitt broth, $10 \mathrm{ml}$ in $15-\mathrm{ml}$ screw-capped bottles, was inoculated with $0.5 \mathrm{ml}$ of a fresh broth culture of streptococci and incubated overnight at $37^{\circ} \mathrm{C}$. The turbidity of the cultures was determined in a spectrophotometer $(650 \mathrm{~nm})$ and only those with an optical density of $0 \cdot 8-1.0$ were used. These cultures were centrifuged and the supernatant fluids were removed and sterilised by filtration through Oxoid membranes $(0.45 \mu \mathrm{m})$ in Hemming's centrifugal filters.

Investigation of mitogenic activity. Human peripheral-blood lymphocytes were obtained and cultured as previously described (Taylor). From the culture supernatants to be tested $0.1 \mathrm{ml}$ was added to each of two lymphocyte cultures containing $10^{6}$ cells in $1 \mathrm{ml}$ of medium. For each test, positive and negative control cultures were also examined; the negative control received uninoculated broth and the positive control the supernatant from a broth culture of strain Blackmore, known to be strongly mitogenic. After incubation for $24 \mathrm{hr}, 0 \cdot 1 \mu \mathrm{Ci}$ of thymidine-2-C14 (Radiochemical Centre, Amersham, Bucks.) was added and incubation was continued for another $24 \mathrm{hr}$. The number of surviving cells in each culture was then determined in a haemacytometer; $0.05-\mathrm{ml}$ volumes were added to equal volumes of leucocytediluting fluid. The cultures were filtered through Swinnex filters with glass-fibre filter disks (Millipore Ltd) as described by Sorensen, Andersen and Giese (1969). The disks were transferred to scintillation-counting vials with $10 \mathrm{ml}$ phosphor $\{0.5$ per cent. butyl-PBD (Ciba

Received 20 May 1971; accepted 11 Aug. 1971.

J. MED. MICROBIOL.-VOL. 5 (1972) 
Ltd) in toluene\}. Counts were corrected for quenching by external standardisation, and the activity of each culture was expressed as disintegrations per minute (d.p.m.) per $10^{6}$ surviving lymphocytes.

The thymidine uptake induced by $0.1 \mathrm{ml}$ of test supernatant was compared with the thymidine uptake in the same batch of lymphocytes induced by $0.1 \mathrm{ml}$ of positive-control broth supernatant, to give a " mitogenic index":

$$
\text { mitogenic index }=\frac{T-N}{P-N} \times 100
$$

where $\mathbf{T}=$ mean activity (d.p.m.) of two test cultures,

$\mathbf{P}=$ mean activity (d.p.m.) of two positive control cultures,

$\mathbf{N}=$ mean activity (d.p.m.) of two negative control cultures.

In most cases a third lymphocyte-culture tube for each supernatant was included to allow microscopic examination for transformed cells after 5 days' incubation. The volume of supernatant added was $0.1 \mathrm{ml}$ and the technique was as described previously (Taylor).

\section{RESULTS}

Culture supernatants from all 27 strains of group-A streptococci gave a high mitogenic index (table I). To exclude the possibility that the increased thymidine uptake was due to transformation of lymphocytes of sensitised donors by

\section{TABLE I}

Mitogenic activity on human lymphocytes of supernatants from broth cultures of group- $A$ streptococci

\begin{tabular}{|c|c|c|c|}
\hline $\begin{array}{c}\text { Strain } \\
\text { number }\end{array}$ & M-type & $\begin{array}{l}\text { Mitogenic } \\
\text { index }\end{array}$ & $\begin{array}{l}\text { Percentage of } \\
\text { transformed cells }\end{array}$ \\
\hline $\begin{array}{l}8198^{*} \\
8322^{*} \\
100064 \\
\text { R70/3067 } \\
\text { R70/3251 } \\
100065 \\
8302^{*} \\
100067 \\
\text { R59/2653 } \\
10068 \\
\text { R70/2179 } \\
\text { R70/1555 } \\
100085 \\
100070 \\
8320^{*} \\
\text { R68/1663 } \\
\text { R71/80 } \\
\text { R68/616 } \\
\text { R68/98 } \\
8301 * \\
\text { R70/740 } \\
\text { R63/10 } \\
\text { R68/3306 } \\
\text { R68/2568 } \\
8195^{*} \\
8227^{*} \\
8230^{*}\end{array}$ & $\begin{array}{r}1 \\
2 \\
3 \\
3 \\
3 \\
5 \\
6 \\
9 \\
11 \\
11 \\
11 \\
11 \\
12 \\
15 \\
18 \\
22 \\
22 \\
22 \\
22 \\
23 \\
24 \\
24 \\
26 \\
26 \\
30 \\
36 \\
46\end{array}$ & $\begin{array}{r}312 \\
210 \\
72 \\
78 \\
38 \\
146 \\
116 \\
189 \\
260 \\
47 \\
28 \\
86 \\
114 \\
54 \\
80 \\
48 \\
74 \\
82 \\
83 \\
57 \\
157 \\
75 \\
60 \\
65 \\
102 \\
82 \\
73\end{array}$ & $\begin{array}{l}\ldots \dagger \\
\ldots \\
\ldots \\
70 \\
50 \\
\ldots \\
\ldots \\
\ldots \\
\ldots \\
60 \\
70 \\
\ldots \\
\ldots \\
70 \\
70 \\
70 \\
70 \\
70 \\
70 \\
70 \\
70 \\
\ldots \\
\ldots \\
\ldots\end{array}$ \\
\hline
\end{tabular}


TABLE II

Mitogenic activity of supernates from broth cultures of streptococci of various Lancefield groups

\begin{tabular}{|c|c|c|c|c|c|}
\hline Group & Serotype or species & $\begin{array}{c}\text { Strain } \\
\text { designation }\end{array}$ & $\begin{array}{l}\text { Mitogenic } \\
\text { index }\end{array}$ & $\begin{array}{l}\text { Percentage of } \\
\text { transformed cells }\end{array}$ & $\begin{array}{l}\text { Mitogenic } \\
\text { activity* }\end{array}$ \\
\hline $\begin{array}{l}\mathbf{B} \\
\mathbf{B} \\
\mathbf{B} \\
\mathbf{B}\end{array}$ & $\begin{array}{l}\text { Ia } \\
\text { Ib } \\
\text { II } \\
\text { III }\end{array}$ & $\begin{array}{l}\text { O90 } \\
\text { H36B (RCL) } \\
\text { 18RS21 (RCL) } \\
\text { D136C }\end{array}$ & $\begin{array}{l}3 \cdot 9 \\
1 \cdot 6 \\
4 \cdot 6 \\
3 \cdot 1\end{array}$ & $\begin{array}{r}15 \\
3 \\
15 \\
2\end{array}$ & $\begin{array}{l}- \\
\overline{-} \\
-\end{array}$ \\
\hline $\begin{array}{l}\mathrm{C} \\
\mathbf{C} \\
\mathrm{C} \\
\mathrm{C} \\
\mathrm{C} \\
\mathrm{C} \\
\mathrm{C}\end{array}$ & $\begin{array}{l}\text { Str. zooepidemicus } \\
\text { Str. zooepidemicus } \\
\text { Str. equisimilis } \\
\text { Str. equi } \\
\text { Str. equi } \\
\text { Str. equi } \\
\text { Str. equi }\end{array}$ & $\begin{array}{l}\text { D181 } \\
\text { R70/2246 } \\
\text { NCTC4540 } \\
\text { R70/2244 } \\
53 / 54 \\
35 / 55 \\
37 / 55\end{array}$ & $\begin{array}{l}8 \cdot 7 \\
117 \\
90 \\
300 \\
108 \\
62 \\
100\end{array}$ & $\begin{array}{r}3 \\
50 \\
60 \\
65 \\
67 \\
45 \\
70\end{array}$ & $\begin{array}{l}- \\
+ \\
+ \\
+ \\
+ \\
+ \\
+\end{array}$ \\
\hline $\begin{array}{l}\text { D } \\
\text { D } \\
\text { D } \\
\text { D }\end{array}$ & $\begin{array}{l}\text { Str. faecalis } \\
\text { Str. faecium } \\
\text { Str. durans } \\
\text { Str. bovis }\end{array}$ & $\begin{array}{l}775 \\
\text { HGH511 } \\
98 D \\
\text { Rosalie }\end{array}$ & $\begin{array}{l}1 \cdot 8 \\
2 \cdot 9 \\
0 \cdot 8 \\
5 \cdot 3\end{array}$ & $\begin{array}{l}2 \\
3 \\
5 \\
8\end{array}$ & $\begin{array}{l}- \\
- \\
-\end{array}$ \\
\hline $\mathrm{E}$ & & 49116 & 1 & 2 & - \\
\hline $\begin{array}{l}\mathrm{F} \\
\mathrm{F}\end{array}$ & & $\begin{array}{l}\text { R70/2178 } \\
\text { O'Mahoney }\end{array}$ & $\begin{array}{l}1 \cdot 8 \\
1\end{array}$ & $\begin{array}{l}1 \\
6\end{array}$ & - \\
\hline $\begin{array}{l}\mathbf{G} \\
\mathbf{G} \\
\mathbf{G}\end{array}$ & & $\begin{array}{l}\mathrm{R} 70 / 2496 \\
\mathrm{R} 70 / 2433 \\
\text { Valente }\end{array}$ & $\begin{array}{r}48 \\
35 \\
6\end{array}$ & $\begin{array}{r}40 \\
75 \\
8\end{array}$ & $\begin{array}{l}+ \\
+ \\
-\end{array}$ \\
\hline $\begin{array}{l}\mathbf{H} \\
\mathbf{H} \\
\mathbf{H} \\
\mathbf{H} \\
\mathbf{H}\end{array}$ & & $\begin{array}{l}\text { Blackburn } \\
3437 / 48 \\
\text { Challis } \\
5042 / 48 \\
868 / 49\end{array}$ & $\begin{array}{c}7 \cdot 2 \\
14 \\
1 \\
1 \\
5 \cdot 4\end{array}$ & $\begin{array}{l}3 \\
2 \\
2 \\
1 \\
4\end{array}$ & $\begin{array}{l}- \\
\overline{-} \\
\overline{-}\end{array}$ \\
\hline $\begin{array}{l}\mathbf{K} \\
\mathbf{K} \\
\mathbf{K}\end{array}$ & & $\begin{array}{l}\text { Levy } \\
\text { Turner } \\
\text { R51/551 }\end{array}$ & $\begin{array}{l}1 \cdot 5 \\
6 \cdot 8 \\
1\end{array}$ & $\begin{array}{l}5 \\
2 \\
1\end{array}$ & $\begin{array}{l}- \\
-\end{array}$ \\
\hline $\begin{array}{l}L \\
L \\
L \\
L \\
L \\
L\end{array}$ & & $\begin{array}{l}\text { SHC16 } \\
\text { SHC146 } \\
\text { R65/3365 } \\
\text { R66/2047 } \\
\text { SHC282 } \\
\text { NCTC7868 }\end{array}$ & $\begin{array}{l}6 \cdot 6 \\
7 \cdot 8 \\
4 \cdot 2 \\
6 \cdot 7 \\
5 \cdot 4 \\
1\end{array}$ & $\begin{array}{l}1 \\
3 \\
4 \\
8 \\
5 \\
1\end{array}$ & $\begin{array}{l}- \\
= \\
= \\
=\end{array}$ \\
\hline $\begin{array}{l}\mathbf{N} \\
\mathbf{P} \\
\mathbf{Q} \\
\mathbf{R}\end{array}$ & Str. lactis & $\begin{array}{l}\text { NCTC6681 } \\
54 / 851 \\
\text { E6844 } \\
735\end{array}$ & $\begin{array}{l}1 \\
1 \\
8 \cdot 9 \\
9 \cdot 1\end{array}$ & $\begin{array}{l}7 \\
6 \\
3 \\
8\end{array}$ & $\begin{array}{l}- \\
- \\
-\end{array}$ \\
\hline
\end{tabular}

$*+=$ Mitogenic activity indicated by mitogenic index $>25$ or by $>20$ per cent. of transformed cells.

$-=$ No mitogenic activity. 
specific antigen, the mitogenic index was determined for lymphocyte cultures from Mantoux-positive donors, in the presence of PPD*. The optimum concentration of PPD for maximal thymidine uptake during the last $24 \mathrm{hr}$ of a 72-hr culture period was $125-250 \mu \mathrm{g}$. With PPD concentrations within this range, the mitogenic index was never greater than 20 and the number of transformed cells seen in smears was not more than 15 per cent. Lymphocytes from two donors were incubated with streptolysin $\mathrm{O}$ and showed much lower levels of stimulation. It was concluded that a mitogenic index of more than 25 , or the presence of more than 20 per cent. lymphoblasts gave a strong indication of non-specific transformation due to the presence of streptococcal mitogen. All group-A strains investigated were therefore considered to be producers of streptococcal mitogen in broth culture.

The strains of other Lancefield groups examined in this study, with the exception of some group-C and group-G strains, showed low mitogenic indices (table II) and it seems that these strains do not produce the mitogen in significant amounts. Six of these seven group-C strains and two of the three group-G strains examined produced mitogenic activity.

\section{Discussion}

The results of these tests with human lymphocytes indicate that the production of the streptococcal non-specific lymphocyte mitogen may be confined to strains belonging to the Lancefield groups A, C, and G. The role of the mitogen in human infection is not known, but it is noteworthy that the common pathogenic streptococci of man belong to these three groups. Study of the mitogenic action of culture supernatants from strains of other Lancefield groups on lymphocytes of their typical hosts might be rewarding.

Some speculation can be made on the significance of the mitogen in vivo. For example, Ginsburg et al. (1968) produced lesions in the myocardium of rabbits by the intratonsillar injection of a pool of extracellular products from a group-A streptococcus. This pool contained deoxyribonuclease, ribonuclease, nicotinamide-adenine-nucleotidase, hyaluronidase, and streptokinase. The mechanism by which the lesions were induced was not understood; but in the light of the present study it seems likely that the pool used by Ginsburg et al. was mitogenic as the preparation was derived directly from unpurified culture supernatants. The possibility that the mitogen is involved in the tissuedamaging process should therefore be considered.

Activated lymphocytes are known to release several soluble factors, termed "lymphokines" by Dumonde et al. (1969). These include a lymphocyte mitogenic factor, an inflammatory factor, and a cytotoxic factor (Kolb and Granger, 1968). These lymphokines are possibly involved in the inflammation of delayed hypersensitivity and in the rejection of tissue allografts.

If the streptococcal mitogen activates lymphocytes in vivo as well as in vitro, these potentially cytotoxic cells may migrate into the myocardial tissue and there

* Tuberculin, purified protein derivative (PPD), 50,000 IU per mg (Ministry of Agriculture, Central Veterinary Laboratory, Weybridge, Surrey). 
initiate the type of lesion reported by Ginsburg et al. The possibility that a similar reaction occurs after streptococcal infection of the human pharynx should be considered in relation to the aetiology of rheumatic fever. A study of the effects of activated lymphocytes in vivo has therefore been started.

\section{SUMMARY}

Broth cultures of 27 strains of group-A streptococci and 39 strains of various other Lancefield groups were tested for lymphocyte-transforming activity. All the group-A strains and most of the group-C and group-G strains were strongly mitogenic. The possible significance of the mitogen in streptococcal infection is discussed.

I am grateful to Professor C. H. Lack, in whose department this work was carried out, for much helpful discussion. My thanks are due to Dr W. R. Maxted for advice and for supplying the cultures of streptococci.

\section{REFERENCES}

BerNheImer, A. W. 1949. Formation of a bacterial toxin (streptolysin S) by resting cells. J. Exp. Med., $90,373$.

Dumonde, D. C., Wolstencroft, R. A., Panay,, G. S., Matthew, Margaret, Morley, J., AND Howson, W. T. 1969. " Lymphokines": non-antibody mediators of cellular immunity by lymphocyte activation. Nature, Lond., 224, 38.

Ginsburg, I., ZeIrI, N., BeNTwich, Z., Boss, J. H., AND HARRIs, T. N. 1968. Organ lesions produced in rabbits following the intratonsillar injections of group A streptococci and some of their products. In Current research on group A streptococcus, ed. by $\mathbf{R}$. Caravano, Amsterdam, p. 162.

HirschHorn, K., Schreibman, R. R., Verbo, S., and Gruskin, R. H. 1964. The action of streptolysin $\mathbf{S}$ on peripheral lymphocytes of normal subjects and patients with acute rheumatic fever. Proc. Natn. Acad. Sci. USA, 52, 1151.

Kolb, W. P., and Granger, Gale A. 1968. Lymphocyte in vitro cytotoxicity: characterization of human lymphotoxin. Proc. Natn. Acad. Sci. USA, 61, 1250.

Plate, J. M., AND Amos, D. B. 1969. Studies on a lymphocyte activating factor from group A streptococci. In Proceedings of the Third Annual Leucocyte Culture Conference, Nov. 1967, ed. by W. O. Rieke, New York.

SORENSEN, S. F., ANDERSEN, V., AND GIESE, J. 1969. A rapid method for quantitation of the incorporation of ${ }^{3} \mathrm{H}$-thymidine by lymphocytes in vitro. Acta path. microbiol. scand., $75,508$.

TARANTA, A., CuPPari, G., AND Quagliata, F. 1969. Dissociation of hemolytic and lymphocyte-transforming activities of streptolysin S preparations. J. Exp. Med., 129, 605.

TAYLOR, A. G. 1969. The nature of the lymphocyte mitogen in streptolysin S. Life Sci., 8, 1281. 